\title{
New host and country records for European Tachinidae (Diptera)
}

\section{Petr Mückstein, Hans-Peter Tschorsnig, Jaromír Vaňhara* \& Veronika Michalková}

\author{
Mückstein, P., Tschorsnig, H.-P., Vaňhara, J. \& Michalková, V. 2007: New host \\ and country records for European Tachinidae (Diptera). — Entomol. Fennica 18: \\ 179-183.
}

The paper presents host records for 17 species of Tachinidae (of subfamilies Exoristinae and Tachininae) from the Czech Republic, Slovakia, Austria, Croatia, Macedonia, Italy, Spain, Portugal, and Bulgaria. New parasitoid-host couples are Exorista larvarum - Melanchra pisi; Exorista segregata - Catocala nymphaea; Sturmia bella - Hadena compta; Spallanzania multisetosa-Cycnia sordida (first host record); Tachina praeceps - Cucullia bubaceki; and Bithia modesta - Bembecia megillaeformis. New country records of tachinid species Rhacodinella apicata from the Czech Republic, Masicera pavoniae from Macedonia and Bithia demotica from Portugal are presented.

P. Mückstein, Administration of the Protected Landscape Area Žd'árské vrchy, Brněnská 39, CZ - 59101 Žd'ár nad Sázavou, Czech Republic; E-mail: muckstein@email.cz

H.-P. Tschorsnig, Staatliches Museum für Naturkunde, Rosenstein 1, D-70 191

Stuttgart, Germany; E-mail: tschorsnig.smns@naturkundemuseum-bw.de J. Vaňhara (*corresponding author), Masaryk University, Faculty of Science, Kotlářská 2, 61137 Brno, Czech Republic; E-mail: vanhara@sci.muni.cz V. Michalková, Masaryk University, Faculty of Science, Kotlářská 2, 61137 Brno,Czech Republic; E-mail:vmichalkova@yahoo.com

Received 20 October 2006, accepted 8 December 2006

\section{Introduction}

The tachinid fauna of Europe is well known, but new records are done every year. Information on distribution of the European Tachinidae is available on-line in Fauna Europaea (Tschorsnig et al. 2005), for the Czech Republic see Vaňhara et al. (2004). New on-line and CD versions of the checklist for the Czech Republic and Slovakia were completed by Vaňhara and Tschorsnig (2006).

All tachinids are parasitoids of insects or other arthropods. Knowledge on their biology, including host insect species is still rather poor. Many problems concerning the host specificity of this large family have not been solved yet, so every host record is important. The short history concerning the research on hosts. has been presented in our previous paper (Mückstein et al. 2004), including general references.

At present, the authors look for further tachinid hosts by the systematic cooperation particularly with lepidopterologists, who contribute reared tachinids from their breeding of caterpil- 
lars from the Czech Republic. But findings from this country yield only a small part of new results. After 1989 our lepidopterologists started freely move out for collection abroad, and so there are new hosts especially from southern and western Europe.

\section{Material and methods}

As far as not explicitly cited in the text, information on hosts is based on a critical host catalogue for the Czech Tachinidae which is currently compiled by the same authors of the present paper and on Tschorsnig's database on Palaearctic host records (unpubl.).

The tachinid species were identified by the authors of the present paper, hosts by the collectors. Nomenclature and arrangement of the tachinids follow Herting and Dely-Draskovits (1993), the names of the lepidopteran hosts follow Karsholt and Razowski (1996).

The material provided by various breeders is stored in the collections of P. Mückstein (cM) and J. Vaňhara $(\mathrm{cV})$.

\section{Faunistic records}

\subsection{Exoristinae}

\subsubsection{Exorista larvarum (Linnaeus, 1758)}

Material: 3 우, reared from Melanchra pisi (Linnaeus) (Lepidoptera, Noctuidae), Czech Republic, Moravia, Přeckov, 1984, leg. Z. Laštůvka $(\mathrm{cM}, \mathrm{cV}) ; 2 \widehat{\widehat{\partial}}$, reared from pupa of Euthrix potatoria (Linnaeus) (Lepidoptera, Lasiocampidae), Czech Republic, Bohemia, Týniště nad Orlicí, 13.VII.1986, leg. J. Voda (cM).

Notes: A common tachinid which develops in many lepidopteran families.

Melanchra pisi is a new host record.

\subsubsection{Exorista segregata (Rondani, 1859)}

Material: 1 , reared from Catocala nymphaea (Esper) (Lepidoptera, Noctuidae), Spain, Andalusia, NW Sierra Nevada, El Molinillo near Diezma, 1200 m a.s.1., VII.2004, leg. Z. Laštůvka (cV).
Notes: Exorista segregata is an unspecialised species (common in southern Europe), parasitising many lepidopteran families.

Catocala nymphaea is a new host record.

\subsubsection{Meigenia mutabilis (Fallén, 1810)}

Material: 1 , reared from larva of Gastrophysa viridula (Degeer) (Coleoptera, Chrysomelidae), Czech Republic, Praha, Ruzyně, 10.VI.2003, leg. M. Honěk (cM).

Notes: A common parasitoid of Coleoptera larvae. Already known from the host Gastrophysa viridula (many records).

Gastrophysa viridula is a new host record for the Czech Republic.

\subsubsection{Compsilura concinnata (Meigen 1824)}

Material: 2 우, reared from Aglaope infausta (Linnaeus) (Lepidoptera, Zygaenidae), Portugal, Bragança, VII.2004, leg. Z. Laštůvka (cV).

Notes: Compsilura concinnata is the tachinid species with the highest number of known host species (currently at least 230 in the Palaearctic). Aglaope infausta was already known as host from Spain and France (Benlloch \& Cañizo 1934, Herting 1960).

Aglaope infausta is a new host record for Portugal.

\subsubsection{Winthemia quadripustulata} (Fabricius, 1794)

Material: 19 , reared from larva of Cucullia lactucae (Denis \& Schiffermüller) (Lepidoptera, Noctuidae), Czech Republic, Rokytnice nad Jizerou, 30.VII.2003, leg. L. Traxler (cM).

Notes: Hosts of this common species are mainly Noctuidae. Herting (1960) records $\mathrm{Cu}$ cullia lactucae as a host from Germany.

Cucullia lactucae is a new host record for the Czech Republic.

\subsubsection{Phryxe prima \\ (Brauer \& Bergenstamm, 1889)}

Material: 1 , reared from larva of Zygaena carniolica (Scopoli) (Lepidoptera, Zygaenidae), Czech Republic, Bohemia, Květná near Lito- 
myšl, TCP Stráně 6264C, 18.VII.1998, leg. B. Mocek (cV).

Notes: A parasitoid of Zygaena spp. Already known from the host Zygaena carniolica.

Zygaena carniolica is a new host record for Phryxe prima from the Czech Republic.

\subsubsection{Lydella stabulans (Meigen, 1824)}

Material: 1 , reared from Hydraecia micacea (Esper) (Lepidoptera, Noctuidae), Czech Republic, Bohemia, Píšt'any near Louny, 10.VII.2002, leg. Šedivý (cV).

Notes: A known parasitoid of noctuid larvae which feed hidden in stems of herbaceous plants. Hydraecia micacea is a common host of Lydella stabulans.

Hydraecia micacea is a new host record for the Czech Republic.

\subsubsection{Huebneria affinis (Fallén, 1810)}

Material: $1 \hat{\jmath}$, reared from Arctia caja (Linnaeus) (Lepidoptera, Arctiidae), Czech Republic, Bohemia, Vracov, VII.1983, leg. Havel ["59884"] (cV); 1 \&, same host, Czech Republic, Moravia, Karlova Studánka env., 29.V.2003, leg. L. Traxler (cM); 1 ô, same host, Slovakia, Strážcovské vrchy, Široká dolina, 18.VI.2004, leg. J. Rybár (cV).

Notes: Usually a common parasitoid of Arctiidae. There are numerous records from the host Arctia caja.

Arctia caja is a new host record for Huebneria affinis from the Czech Republic.

\subsubsection{Carcelia rasa (Macquart, 1849)}

Material: 1 ग, 2 우, reared from larva of Calliteara pudibunda (Linnaeus) (Lepidoptera, Lymantriidae), Czech Republic, Bohemia, Týniště nad Orlicí, 16.XII.1986, leg. J. Voda (cM).

Notes: This species develops in Lymantriidae. Known from many countries as parasitoid of Calliteara pudibunda.

Calliteara pudibunda is a new host record for Carcelia rasa from the Czech Republic.

\subsubsection{Rhacodinella apicata (Pandellé, 1896)}

Material: 1 ( (in bad condition), reared from pupa of Phyllodesma ilicifolia (Linnaeus) (Lepidoptera, Lasiocampidae), Czech Republic, Př́íbram, 28.VI.2002, leg. L. Traxler (cM).

Notes: An unspecialised and normally rare species. The host Phyllodesma ilicifolia is already recorded by Herting (1960) from Switzerland.

The tachinid species Rhacodinella apicata is recorded for the first time from the Czech Republic.

\subsubsection{Sturmia bella (Meigen, 1824)}

Material: 1 q, reared from Hadena compta (Denis \& Schiffermüller) (Lepidoptera, Noctuidae), Austria, Dachstein-Gruppe, Ramsau a. D., 465' ' N, 1336' E, 26.-31.VII.2003, leg. V. Červenka $(\mathrm{cV})$.

Notes: A common species which is predominantly reared from Nymphalidae, but also members of several other lepidopteran families are known as hosts, including a few Noctuidae.

Hadena compta is a new host record.

\subsubsection{Masicera pavoniae}

(Robineau-Desvoidy, 1830)

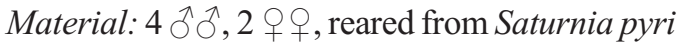
(Denis \& Schiffermüller) (Lepidoptera, Saturniidae), Croatia, Istria, Rabac, IV.2005, leg. Z. Laštůvka (cV); 2 +, , same host, Bulgaria, Zlaté Písky, 5.V.1963, leg. V. Zeman (cM); 2 ふ઼, 5 우, reared from Saturnia spini (Denis \& Schiffermüller), Macedonia, Tetovo, 15.V.1992, leg. L. Traxler (cM.)

Notes: Masicera pavoniae is - as a main parasitoid of Saturnia spp. - often reared from S. pyri and $S$. spini. One of the four males of the series from Croatia is aberrant because it shows two proclinate orbital bristles (instead of one).

The tachinid species Masicera pavoniae is recorded for the first time from Macedonia. 


\subsubsection{Spallanzania multisetosa}

(Rondani, 1859)

Material: 1 , reared from Cycnia sordida (Hübner) (Lepidoptera, Arctiidae), Italy, Vall d'Aosta, VII.2003, (cV).

Notes: Spallanzania multisetosa is not rare in southern Europe and the warmer parts of the Alps. Other species of the genus Spallanzania, $S$. hebes and $S$. rectistylum, are known as parasitoids of Noctuidae. It would be of interest to revise the old record of "Cnephalia bucephala" reared from the arctiid Phragmatobia fuliginosa, as it cannot be ruled out that this might have been S. multisetosa. This record, however, is only cited in a footnote of Bezzi (1907) and given without any reference.

Cycnia sordida is the first host record.

\subsection{Tachininae}

\subsubsection{Tachina praeceps Meigen, 1824}

Material: 1 ô, reared from Cucullia bubaceki Kitt (Lepidoptera, Noctuidae), Spain, Aragón, Belchite, 41 ${ }^{\circ} 25^{\prime} 30^{\prime \prime}$ N, 0045'02 E, 22”.X.2003, leg. V. Červenka (cV).

Notes: A predominantly southern European species which develops in various host families (Lymantriidae, Lasiocampidae, Arctiidae, Noctuidae, Sphingidae).

Cucullia bubaceki is a new host record.

\subsubsection{Bithia demotica (Egger, 1861)}

Material: 1 , , reared from Bembecia psoraleae Bartsch \& Bettag (Lepidoptera, Sesiidae), Portugal, Algarve, Messines Baixo, 25.VII.2003, leg. Z. Laštůvka (cV).

Notes: A parasitoid of Sesiidae (Bembecia, Chamaesphecia, Synansphecia). Bembecia psoraleae was recorded as host by Bartsch and Bettag (1997) from Spain.

The tachinid species Bithia demotica is recorded for the first time from Portugal.

\subsubsection{Bithia glirina (Rondani, 1861)}

Material: 1 o, 1 , , reared from larva of Chamaesphecia empiformis (Esper) (Lepidoptera, Sesiidae), Slovakia, Hrádok nad Váhom, 1987, leg. Z. Laštůvka (cM).

Notes: A parasitoid of Sesiidae (Chamaesphecia, Bembecia). Chamaesphecia empiformis was already recorded as host by Herting (1960).

Chamaesphecia empiformis is the first host record for Slovakia.

\subsubsection{Bithia modesta (Meigen, 1824)}

Material: 3 กิ $\hat{0}, 1$, reared from larva of Bembecia megillaeformis (Hübner) (Lepidoptera, Sesiidae), Slovakia, Zádiel, 25.VII.1987, 1990 and 1993, leg. Z. Laštůvka (cM, cV); 2 q $q$ (in bad condition), reared from Synansphecia triannuliformis (Freyer) (Lepidoptera, Sesiidae), Bulgaria, Mičurin, VI.1982, leg. Z. Laštůvka (cV).

Notes: A parasitoid of Sesiidae (Bembecia, Synansphecia, Pyropteron).

Bembecia megillaeformis is a new host record.

Acknowledgements. The reared material was kindly provided by L. Traxler (Pardubice, CZ), B. Mocek (Hradec Králové, $\mathrm{CZ}), \mathrm{Z}$. Laštůvka (Brno, $\mathrm{CZ}$ ) and $\mathrm{P}$. Bitušík (Bánská Štiavnica, SK). For financial supporting we are indebted to the Ministry of Education/Masaryk University (MSM 0021622416) and the Grant Agency CR (524/ 05/H536).

\section{References}

Bartsch, D. \& Bettag, E. 1997: Eine neue Art der Gattung Bembecia Hübner, 1819 aus Südwesteuropa: Bembecia psoraleae spec. nov. (Lepidoptera: Sesiidae). Nachr. ent. Ver. Apollo 18: 29-40.

Benlloch, M. \& Cañizo, J. del 1934: Las plagas de Aglaope infausta L. - Bol. Pat. veg. Ent. agric. 7: 115-129.

Bezzi, M. 1907: Tachinidae. — In: Becker, T., Bezzi, M., Kertesz, K. \& Stein, P. (eds.), Katalog der paläarktischen Dipteren 3: 189-597, Budapest.

Herting, B. 1960: Biologie der westpaläarktischen Raupenfliegen (Dipt., Tachinidae). - Monographien zur angewandten Entomologie 16. P. Parey, Berlin. 188 pp.

Herting, B. \& Dely-Draskovits, A. 1993: Family Tachini- 
dae. - In: Soós, A. \& Papp, L. (eds), Catalogue of Palaearctic Diptera 13: 118-624. Hung. Nat. Hist. Mus., Budapest.

Karsholt,, O. \& Razowski, J. 1996: The Lepidoptera of Europe. A distributional checklist. - Apollo Books, Stenstrup. 380 pp.

Mückstein, P., Tschorsnig, H.-P. \& Vaňhara., J. 2004: Some new host records of West Palaearctic Tachinidae (Diptera). — In: Bitušík, P. (ed.), Dipterologica bohemoslovaca, 12. Acta Fac. Ecol. Zvolen 12 (Suppl.): 111-113.

Tschorsnig, H.-P., Richter, V. A., Cerretti, P., Zeegers, T., Bergström, C., Vaňhara, J., Van de Weyer, G., By- strowski, C., Raper, C., Ziegler, J. \& Hubenov, Z. 2005: Tachinidae. — In: Fauna Europaea Service, 1.2 [www document]. URL http://www.faunaeur.org (accessed June 2006).

Van̆hara, J. \& Tschorsnig, H.-P., 2006. Tachinidae Robineau-Desvoidy 1830. — In: Jedlička, L., Kúdela, M., Stloukalová, V. (eds), Checklist of Diptera of the Czech Republic and Slovakia. - Electronic version 1, CD ROM edition, Comenius Univ., Bratislava.

Vaňhara, J., Tschorsnig, H.-P. \& Barták., M. 2004: New records of Tachinidae (Diptera) from the Czech Republic and Slovakia, with a revised check-list. - Stud. Dipt. 10 (2003): 679-701. 